\title{
STAPHYLOCOCCUS SPP. IN THE ORAL CAVITY AND PERIODONTAL POCKETS OF CHRONIC PERIODONTITIS PATIENTS
}

\author{
Jussara Cia S. Loberto ${ }^{1 *}$; Clélia Ap. de Paiva Martins ${ }^{2}$; Silvana S. Ferreira dos Santos ${ }^{1}$; José Roberto Cortelli ${ }^{1}$; \\ Antonio Olavo Cardoso Jorge ${ }^{1,2}$ \\ ${ }^{1}$ Departamento de Odontologia, Universidade de Taubaté, Taubaté, SP, Brasil; ${ }^{2}$ Faculdade de Odontologia, Universidade \\ Estadual Paulista, São José dos Campos, SP, Brasil.
}

Submitted: May 27, 2003; Returned to authors: November 12, 2003; Approved: April 13, 2004.

\begin{abstract}
Staphylococcus spp are not usually isolated from the oral cavity, and when this occurs, they are considered to belong to the transitory microbiota. Individuals with periodontal disease represent possible reservoirs of these opportunistic bacteria in the oral cavity. The use of antibiotics for treatment of periodontal disease or other infections may predispose to the increase of the number of Staphylococcus spp. in the oral cavity. These microorganisms easily become resistant to antibiotics, and may result in superinfection. The purpose of this study was to evaluate the presence of Staphylococcus spp. in the oral cavity and in periodontal pockets of patients with chronic periodontitis, identify the isolates and verify the relationship between the presence of Staphylococcus spp. in the oral cavity and presence of periodontal pockets. The study included eighty-eight patients, 25-60 years of age, with chronic periodontitis, and at least two sites with probing depth $\geq 5 \mathrm{~mm}$. Individual data examination was assessed. Then, samples were colleted from the periodontal pocket with the aid of paper tips and from the oral cavity through mouth rinses. Out of the total of patients, $37.50 \%$ presented Staphylococcus spp. in the periodontal pocket and $61.36 \%$ in the oral cavity, $27.27 \%$ presented the bacteria in both sites. S. epidermidis was the most prevalent specie in the periodontal pocket $(15.9 \%)$ and oral cavity $(27.27 \%)$. The occurrence of higher proportions of nonresident's microorganisms in subgingival samples and oral sites may represent significant problem in causing and maintaining periodontal infections.
\end{abstract}

Key words: Staphylococcus, opportunistic bacteria, periodontitis

\section{INTRODUCTION}

Staphylococcus spp. display important virulence properties and cause a wide range of human infectious diseases including pneumonia, septicemia, and endocarditis $(1,11,12,13,17,18$, $21,22,23)$. They are not usually isolated from the oral cavity and when it occurs they are considered a part of the transient microbiota. However, a change in the oral microbiota may develop for several reasons. In immunocompromised individuals these microorganisms may occur in higher number. Patients with periodontal disease represent possible reservoirs of these opportunistic bacteria in the oral cavity. They can also be an infection source to other individuals $(3,7,20)$.
The purpose of this study was to evaluate the presence of Staphylococcus spp. in the oral cavity and in periodontal pockets of patients with chronic periodontitis, identify the isolates and verify the relationship between the presence of Staphylococcus spp. in the oral cavity and periodontal pocket.

\section{MATERIALS AND METHODS}

The study included 88 individuals with chronic periodontitis from the Clinic of Periodontology of the University of Taubaté (UNITAU). They were from 25 to 60 years of age and had not received periodontal nor antibiotic treatment. Following the examination, all patients were given instruction regarding to a

*Corresponding author. Mailing address: Rua Major José dos Santos Moreira, 595. 12410-050, Pindamonhangaba, SP, Brasil. Tel.: (+5512) 2424009. Fax: (+5512) 2427871. E-mail: jussara.loberto@uol.com.br 
proper self-performance plaque control. Prior to participation, the purpose and procedures were fully explained to all the patients. They volunteered themselves to participate in the trial and gave their informed consent (16). This study was carried out with the approval of the Ethics Committee of São José dos Campos Dentistry School (UNESP). Probing pocket depth and clinical attachment level were measured using a Williams' probe. Just one examiner, previously calibrated, examined all the patients. After individual data collection and clinical examination, samples of subgingival dental biofilm were obtained in those individuals that had at the time of referred at least two sites with probing depth $\geq 5 \mathrm{~mm}$. At the selected sites, supragengival plaque was removed with the aid of sterilized gauze compress and isolated with cotton rolls. Subgingival dental biofilm samples were collected by inserting 3 sterile paper points (number 30 Áureo) consecutively into the periodontal pocket, for 30 seconds.

The collected material was placed in Eppendorf tubes containing $1 \mathrm{~mL}$ of sterile solution (PBS $0.1 \mathrm{M} / \mathrm{pH} 7.2$ ). Material from oral cavity was collected through oral rinses, during $1 \mathrm{~min}$, in $10 \mathrm{~mL}$ of sterile solution (PBS $0.1 \mathrm{M} / \mathrm{pH}$ 7.2) previously distributed in sterile universal containers. The samples were maintained in ice until the process in the laboratory of Microbiology. The maximum period of 3 hours between collection and processing was respected. Microbiological analysis of the samples were performed in the laboratory of Microbiology, Department of Biology (UNITAU) or in the laboratory of Biosciences and Oral Diagnosis (São José dos Campos School of Dentistry, UNESP)

The material obtained from periodontal pocket was mechanically dispersed with the aid of a Vortex mixer for 30 seconds. After this procedure, the paper points were removed. Each sample (oral rinse and periodontal pocket sample) was centrifuged by $10 \mathrm{~min}(8000 \mathrm{Xg})$ and the supernatant was discharged. The pellet was ressuspended in $2.5 \mathrm{~mL}$ and $0.6 \mathrm{~mL}$ PBS respectively, obtaining the final suspension.

From each sample $0.1 \mathrm{~mL}$ aliquots were plated in duplicate copy onto Baird-Parker agar (Difco) supplemented with egg yolk (12.5 egg yolks in $25 \mathrm{ml}$ saline solution $0.85 \%$ ) and potassium tellurite ( $0.1 \mathrm{~g}$ of potassium tellurite in $10 \mathrm{~mL}$ of distilled water) and were incubated by 24 to 72 hours at $37^{\circ} \mathrm{C}$. After the incubation period, the identification of Staphylococcus isolates was based on colonial morphology and Gram stain characteristics. The strains were then on plated in Tryptic Soy Agar (TSA - Difco) and incubated by 24 hours at $37^{\circ} \mathrm{C}$. Pure cultures were identified according Koneman et al. (6). Coagulase negative Staphylococcus isolates were identified using the system API Staph (Bio-Merièux, France). The bacterial suspension preparation and the inoculation of the trips were carried out as recommended by the manufacturer. The strips were incubated by 24 hours at $37^{\circ} \mathrm{C}$. Based on the biochemical reactions, a seven-digit profile number was assigned to each isolate and the Code book were used for speciation. Chi-square homogeneity test and Chi-square tendency test were used with critical level at $\mathrm{p}<0.05$.

\section{RESULTS}

Out of the 88 patients with chronic periodontitis, staphylococci were isolated from the subgingival sample of 33 patients (37.50\%); from the oral cavity of 54 patients (61.36\%), and $27.27 \%(\mathrm{n}=24)$ presented staphylococci in both sites. S. epidermidis $(\mathrm{n}=14,15.90 \%)$ were isolated from the subgingival samples and $27.27 \%(\mathrm{n}=24)$ from the oral cavity. Five patients $(5.68 \%)$ present $S$. epidermidis in both sites. S. aureus were isolated from $4.55 \%$ of the subgingival samples and $25 \%(\mathrm{n}=22)$ of the oral cavity samples (Table 1). From the 88 studied patients, $39.77 \%$ were males $(n=35)$ and $60.23 \%(n=53)$ females. The prevalence of Staphylococcus spp in the oral cavity of males was significantly higher in relation to the females. The prevalence of subgingival Staphylococcus according to the gender was not statistically significant (Tables 2 and 3). The individuals ranged from 25 to 60 years of age (mean age 40.95) The presence of these microorganisms among the age groups was not statistically different (Tables 4 and 5). In the present

Table 1. Distribution of absolute (n) and relative (\%) frequencies of species staphylococci isolated from the oral cavity and periodontal pocket of patients with chronic periodontitis $(n=88)$.

\begin{tabular}{|c|c|c|c|c|}
\hline \multirow{3}{*}{ Staphylococci Species } & \multicolumn{4}{|c|}{ Isolates } \\
\hline & \multicolumn{2}{|c|}{$\begin{array}{c}\text { Oral } \\
\text { Cavity }\end{array}$} & \multicolumn{2}{|c|}{$\begin{array}{l}\text { Periodontal } \\
\text { Pocket }\end{array}$} \\
\hline & $\mathrm{n}$ & $\%$ & $\mathrm{n}$ & $\%$ \\
\hline S. epidermidis & 19 & 21.59 & 14 & 15.91 \\
\hline S. epidermidis / S. aureus & 4 & 4.55 & 0 & 0.0 \\
\hline S. epidermidis / S. capitis & 1 & 1.14 & 0 & 0.0 \\
\hline S. aureus & 20 & 22.73 & 4 & 4.55 \\
\hline S. aureus / S. hyicus & 1 & 1.14 & 0 & 0.0 \\
\hline S. aureus / S. schleiferi & 1 & 1.14 & 0 & 0.0 \\
\hline S. intermedius & 2 & 2.27 & 6 & 6.82 \\
\hline S. capitis & 2 & 2.27 & 4 & 4.55 \\
\hline S. schleiferi & 1 & 1.14 & 0 & 0.0 \\
\hline S. caprae & 1 & 1.14 & 0 & 0.0 \\
\hline S. haemolyticus & 1 & 1.14 & 0 & 0.0 \\
\hline S. xylosus & 1 & 1.14 & 1 & 1.14 \\
\hline S. hyicus & 0 & 0.0 & 1 & 1.14 \\
\hline S. cohini & 0 & 0.0 & 1 & 1.14 \\
\hline S. warneri & 0 & 0.0 & 2 & 2.27 \\
\hline Total of patient positive & 54 & 61.36 & 33 & 37.50 \\
\hline
\end{tabular}


Table 2. Number of individuals with Staphylococcus spp. in the oral cavity according to the gender.

\begin{tabular}{lcccccc}
\hline Gender & \multicolumn{2}{c}{ Positive cases } & \multicolumn{2}{c}{ Negative cases } & \multicolumn{2}{c}{ Total } \\
& $\mathrm{n}$ & $(\%)$ & $\mathrm{n}$ & $(\%)$ & $\mathrm{n}$ & $(\%)$ \\
\hline Males* & 26 & $(74.28)$ & 9 & $(25.71)$ & 35 & $(100)$ \\
Females & 28 & $(52.83)$ & 25 & $(47.16)$ & 53 & $(100)$ \\
\hline Total & 54 & $(61.36)$ & 34 & $(38.63)$ & 88 & $(100)$ \\
\hline
\end{tabular}

(Significantly statistically $(\mathrm{p}<0.05)$. Chi-square homogeneity test (2 = 4.09; $\mathrm{gl}=1 ; \mathrm{p}=0.0431)$.

Table 3. Number of individuals with subgingival Staphylococcus spp. according to the gender.

\begin{tabular}{lcccccc}
\hline Gender & \multicolumn{2}{c}{ Positive cases } & \multicolumn{2}{c}{ Negative cases } & \multicolumn{2}{c}{ Total } \\
& $\mathrm{n}$ & $(\%)$ & $\mathrm{n}$ & $(\%)$ & $\mathrm{n}$ & $(\%)$ \\
\hline Males & 13 & $(37.14)$ & 22 & $(62.85)$ & 35 & $(100)$ \\
Females & 20 & $(37.73)$ & 33 & $(62.26)$ & 53 & $(100)$ \\
\hline Total & 33 & $(37.50)$ & 55 & $(62.50)$ & 88 & $(100)$ \\
\hline
\end{tabular}

Chi-square homogeneity test $(2=0.00 ; \mathrm{gl}=1 ; \mathrm{p}=0.955)$.

Table 4. Number of individuals that presented Staphylococcus spp. in the oral cavity in according to the age group.

\begin{tabular}{crcrcrc}
\hline $\begin{array}{c}\text { Age group } \\
\text { (years) }\end{array}$ & \multicolumn{2}{c}{ Positive cases } & \multicolumn{2}{c}{ Negative cases } & \multicolumn{2}{c}{ Total } \\
& $\mathrm{n}$ & $(\%)$ & $\mathrm{n}$ & $(\%)$ & $\mathrm{n}$ & $(\%)$ \\
\hline $25-30$ & 6 & $(60)$ & 4 & $(40)$ & 10 & $(100)$ \\
$31-40$ & 20 & $(62.50)$ & 12 & $(37.50)$ & 32 & $(100)$ \\
$41-50$ & 22 & $(59.45)$ & 15 & $(40.54)$ & 37 & $(100)$ \\
$51-60$ & 6 & $(66.66)$ & 3 & $(33.33)$ & 9 & $(100)$ \\
\hline Total & 54 & $(61.36)$ & 34 & $(38.63)$ & 88 & $(100)$ \\
\hline
\end{tabular}

Chi-square tendency test $(2=0.01 ; \mathrm{gl}=1 ; \mathrm{p}=0.918)$.

study, no significant correlation was detected between age and increase of the microorganisms (Table 6 ). The higher number of positive samples for Staphylococcus spp was observed among the individuals between 31 and 40 years old $(56,25 \%)$. For the probing depths between 5 to $6 \mathrm{~mm}, 7$ to $8 \mathrm{~mm}$ and 9 to $10 \mathrm{~mm}$, the prevalence of S. epidermidis was of $15.15 \%, 17.07 \%$ and $14.29 \%$ respectively, for $S$. aureus was respectively of $6.06 \%, 0 \%$ and $14.29 \%$.
Table 5. Number of individuals that presented Staphylococcus spp. in the pocket periodontal according to the age group.

\begin{tabular}{crcrcrc}
\hline $\begin{array}{c}\text { Age group } \\
\text { (years) }\end{array}$ & \multicolumn{2}{c}{ Positive cases } & \multicolumn{2}{c}{ Negative cases } & \multicolumn{2}{c}{ Total } \\
& $\mathrm{n}$ & $(\%)$ & $\mathrm{n}$ & $(\%)$ & $\mathrm{n}$ & $(\%)$ \\
\hline $25-30$ & 6 & $(60)$ & 4 & $(40)$ & 10 & $(100)$ \\
$25-30$ & 1 & $(10)$ & 9 & $(90)$ & 10 & $(100)$ \\
$31-40$ & 18 & $(56.25)$ & 14 & $(43.75)$ & 32 & $(100)$ \\
$41-50$ & 12 & $(32.43)$ & 25 & $(67.56)$ & 37 & $(100)$ \\
$51-60$ & 2 & $(22.22)$ & 7 & $(77.77)$ & 9 & $(100)$ \\
\hline Total & 33 & $(37.50)$ & 55 & $(62.50)$ & 88 & $(100)$ \\
\hline
\end{tabular}

Chi-square tendency test $(2=0.25 ; \mathrm{gl}=1 ; \mathrm{p}=0.617)$.

Table 6. Number of individuals that presented Staphylococcus spp. in the periodontal pocket in according to probing depth.

\begin{tabular}{crcrcrcr}
\hline $\begin{array}{c}\text { Probing } \\
\text { depth }(\mathrm{mm})\end{array}$ & \multicolumn{2}{c}{ Positive cases } & \multicolumn{2}{c}{ Negative cases } & \multicolumn{2}{c}{ Total } \\
& $\mathrm{( \% )}$ & \multicolumn{1}{c}{$\mathrm{n}$} & $(\%)$ & $\mathrm{n}$ & $(\%)$ \\
\hline $5-6$ & 12 & $(36.36)$ & 21 & $(63.63)$ & 33 & $(100)$ \\
$7-8$ & 15 & $(36.58)$ & 26 & $(63.41)$ & 41 & $(100)$ \\
$9-10$ & 6 & $(42.85)$ & 8 & $(57.14)$ & 14 & $(100)$ \\
\hline Total & 33 & $(37.50)$ & 55 & $(62.50)$ & 88 & $(100)$ \\
\hline
\end{tabular}

Chi-square tendency test $(2=0.13 ; \mathrm{gl}=1 ; \mathrm{p}=0.722)$.

\section{DISCUSSION}

Although staphylococci, mainly S. aureus and S. epidermidis, are frequently reported as pathogen causing nosocomial infections and acute problems, they are not frequently studied in the oral cavity. Subgingival staphylococci may not necessarily represent superinfection, but rather a colonization of indigenous oral bacteria. In the view of the virulence properties of these microorganisms, the present study examined the occurrence of these in oral cavity of patients with periodontal diseases. Slots et al. (19) found Staphylococcus spp. in $28.3 \%$ of individuals that were between 25 and sixty years of age. S. aureus was the second most common subgingival staphylococcal species, after S. epidermidis. In the present study, the microorganisms were present in $37.5 \%$ of individuals with similar age group and using similar methodology for the collection of the samples. $S$. epidermidis was present in $15.91 \%$ of the individuals, and was also the most commonly isolated subgingival staphylococcal specie. Our results are in accordance with others studies. Sánchez-Cordero et al. (15) isolated Staphylococcus from subgingival plaque from three groups: control group (10\%), 
including young adults clinically healthy, without evidence of loss of attachment, periodontitis nondiabetics group (17.5\%), presented a pocket depth $\geq 5 \mathrm{~mm}$, and finally, periodontitis diabetics group $(60 \%)$, showed pocket depth $\geq 5 \mathrm{~mm}$ and medically supervised diabetic. There was no significant difference between the control and the periodontitis nondiabetics groups in the incidence of $S$. epidermidis. The diabetic group showed a significantly higher incidence when compared to the pooled control and periodontitis nondiabetics groups and when compared to the control group alone. According to the authors, in the diabetic group, insulin-injecting diabetics made up $62.5 \%$ of the whole group. Thus, it would be reasonable to assume that injections readily penetrate the skin barrier and may easily introduce staphylococci in the subject, but the authors observed that the distribution of the S. epidermidis was independent of the duration of the diabetic state and of oral or parenteral diabetic therapy. Dahlém and Wikström (3) observed positive samples of S. epidermidis in $54.4 \%$ of patients with chronic periodontitis although a lot of them demonstrated recurrent of periodontal attachment and use of antibiotic prior to the sutdy. $S$. aureus was observed in $8.2 \%$ of the patients. Listgarten et al. (8), Edwardsson et al. (4) observed low prevalence of $S$. aureus $(<5 \%)$ in individuals with different probing depth. We found S. aureus in only $4.5 \%(\mathrm{n}=4)$ of individuals and we could not correlate with the probing depth. Many species isolated in this study are not considered part of oral microbiota such as $S$. warneri ( $6 \%$ of positive sample) and S. capitis ( $12.12 \%$ of positive samples). Other studies also found other staphylococci species in the periodontal pocket $(2,5,8,10,14)$. S. hycus $(17 \%)$ and $S$. scheleiferi subspecies coagulans $(6.1 \%)$ were also found in the oral cavity in the study of Martins et al. (9) in health individuals using methodology similar to collect the oral rinses.

Rams et al. (14) reported approximately $50 \%$ of periodontal lesions harbored subgingival staphylococci. In the present study, $33 \%$ of the individuals with probing depth $\geq 5 \mathrm{~mm}$ presented staphylococci. There was not found a correlation between the presence of the microorganisms, age and probing depth. The presence of staphylococci in higher proportions in subgingival dental biofilm cannot be considered super-infection. However, as they can act as an opportunistic microorganism, their presence must be considered during antibiotic therapy. The antibiotic administration can cause selection of resistant strains. The occurrence of higher proportions of nonresident's microorganisms in subgingival samples and oral sites may represent a significant problem in causing and maintaining periodontal infections.

\section{ACKNOWLEDGEMENTS}

This study had the financial support through the PostGraduation-Scholarship Program from the Universidade de Taubaté.

\section{RESUMO}

\section{Staphylococcus spp. na cavidade bucal e na bolsa periodontal de indivíduos com periodontite crônica}

Staphylococcus spp. não são usualmente isolados a partir da cavidade bucal. Quando presentes, são considerados pertencentes à microbiota transitória. Indivíduos que apresentam doença periodontal representam possíveis reservatórios dessas bactérias oportunistas na cavidade bucal. O uso de antibióticos para o tratamento da doença periodontal ou outras infecções pode predispor o aumento do número de Staphylococcus spp. na boca, pois estes adquirem facilmente resistência aos antibióticos, podendo resultar em superinfecção. O objetivo deste estudo foi verificar a presença de Staphylococcus spp. na cavidade bucal e nas bolsas periodontais de pacientes com periodontite crônica; identificar as cepas isoladas; verificar a relação entre a presença de Staphylococcus spp. na cavidade bucal e presença de bolsa periodontal. Participaram deste estudo 88 pacientes, entre 25 e 60 anos de idade e apresentando periodontite crônica, com pelo menos dois sítios com profundidade de sondagem maior ou igual a $5 \mathrm{~mm}$. Após anamnese e exame clínico periodontal foram feitas coletas de material da bolsa periodontal com cones de papel e da cavidade bucal por meio de bochechos. Do total de pacientes $37,50 \%$ apresentaram Staphylococcus spp. na bolsa periodontal e $61,36 \%$ na cavidade bucal, sendo que $27,27 \%$ apresentaram a bactéria nos 2 sítios. S. epidermidis foi a espécie mais prevalente para bolsa periodontal $(15,9 \%) \mathrm{e}$ cavidade bucal $(27,27 \%)$. Não houve diferença estatística significante quanto à presença desses microrganismos entre as faixas etárias e aumento da profundidade de sondagem. A presença de bactérias oportunistas na cavidade bucal pode representar dificuldades para a manutenção do tratamento periodontal.

Palavras-chave: Staphylococcus, bactérias oportunistas, periodontite

\section{REFERENCES}

1. Al-Walli, W.I.; Elvin, S.J.; Mason, C.M.; Clark, A.; Tranter, H.S Comparative phenotypic characteristics of Staphylococcus aureus isolates from line and non-line associated septicemia, CAPD peritonitis, bone/joint infections and healthy nasal carriers. J. Med. Microbiol., v.47, n.3, p.265-74, Mar. 1998

2. Colombo, A.P.; Haffajee, A.D.; Dewhirst, F.E.; Smith, C.M.; Cugini, M.A.; Socransky, S.S. Clinical and microbiological features of refractory periodontitis subjects. J. Clin. Periodontol., 25: 169$180,1998$.

3. Dahlén, G.; Wikström, M. Occurrence of enteric rods, staphylococci and Candida in subgingival samples. Oral Microbiol. Immunol., 10: 42-46, 1995.

4. Edwardsson, S.; Bing, M.; Axtelius, B.; Lindberg, B.; Söderfeldt, B.; Attström, R.S. The microbiota of periodontal pockets with different 
depths in therapy-resistant periodontitis. J. Clin. Periodontol, 26: 143-152, 1999.

5. Iwase, M.; Slots, J.; Berthold, P.; Taichman, N.S. Leukocidal activity of staphylococci isolated from human periodontal lesions. Oral Microbiol. Immunol., 5: 233-236, 1990.

6. Koneman, E.W.; Allen, S.D.; Janda, W.M.; Schreckenberger, P.C. The Gram-positive cocci: part I: Staphylococcus and related organisms. In: Color atlas and textbook of diagnostic microbiology. 5.ed. Philadelphia: Lippincott, 1997. Cap. 11 p.539-76.

7. Listgarten, M.A.; Lai, C.H. Comparative microbiological characteristics of failing implants and periodontally disease teeth. $J$. Periodontol., 70: 431-437, 1999.

8. Listgarten, M.A.; Lai, C.H.; Young, V. Microbial composition and pattern of antibiotic resistance in subgingival microbial samples from patients with refractory periodontitis. J. Periodontol., 64: 155$161,1993$.

9. Martins, C.A.P.; Koga-Ito, C.Y.; Jorge, A.O.C. Presence of Staphylococcus spp. and Candida spp. in the human oral cavity. Braz. J. Microbiol., 33: 236-240, 2002.

10. Moore, W.E.C.; Moore L.V.H. The bacteria of periodontal disease. Periodontol. 2000, v.5, n.2, p.66-77, June 1994.

11. Öhman S.C.; Östeberg, Y.; Dahlén, G.; Landahl, S. The prevalence of Staphylococcus aureus, Enterobacteriaceae species, and Candida species and their relation to oral mucosal lesions in a group of 79-year-olds in Göteborg. Acta Odontol. Scand, v.53, n.1, p.49-54, Feb. 1995.

12. Okabe, K.; Nakagava, K.; Yamamoto, E. Factors affecting the occurrence of bacteremia associated with tooth extraction. Int. J. Oral Maxillofac. Surg., v.24, n.3, p.239-42, June 1995.

13. Patti, J.M.; Bremell, T.; Krajewska-Pietrasik, D.; Abdelnour, A.; Tarkowski, A.; Rydén, C.; Höök, M. The Staphylococcus aureus collagen adhesin is a virulence determinant in experimental septic arthritis. Infect. Immun., v.62, n.1, p.152-61, Jan. 1994.
14. Rams, T.E.; Feik, D.; Slots, J. Staphylococci in human periodontal disease. Oral Microbiol. Immunol., 5: 29-32, 1990.

15. Sánchez-Cordero, S.; Hoffman, H.; Stahl, S.S. Occurrence of Staphylococcus in periodontal pockets of diabetic and nondiabetic adults. J. Periodontol., 50: 109-113, 1979.

16. Santos, S.S.F.; Martins, C.A.P.; Loberto, J.C.S.; Jorge, A.O.C. Prevalência e sensibilidade in vitro de Enterobacteriaceae e Pseudomonas isoladas da cavidade bucal e bolsa periodontal de pacientes com periodontite crônica. Pós-Grad. Rev. Odontol., 5: 74-83, 2002.

17. Scannapieco, F.A.; Ho, A.W. Potential associations between chronic respiratory disease and periodontal disease: analysis of national health and nutrition examination survey III. J. Periodontol., v.72, n.1, p.50-6, Jan. 2001.

18. Scannapieco, F.A.; Mylotte, J.M. Relationships between periodontal disease and bacterial pneumonia. J. Periodontol., v.67, Suppl., p.111422. Oct. 1996.

19. Slots, J.; Feik, A.; Rams, T.E. Age and sex relationships of superinfecting microorganisms in periodontitis patients. Oral Microbiol. Immunol., 5: 305-308, 1990.

20. Van Winkelhoff, A.J.; Rams T.R.; Slots J. Systemic antibiotic therapy in periodontics. Periodontology 2000, 10: 45-78, 1996.

21. Williams, R.C.; Offenbacher, S. Periodontal medicine: the emergence of a new branch of periodontology. Periodontology 2000, v.23, p.9$12,2000$.

22. Williams, R.J.; Smith, R.L.; Schurman, D.J. Septic arthritis. Staphylococcal induction of chondrocyte proteolytic activity. Arthritis. Rheum., v.33, n.4, p.533-41, Apr. 1990

23. Younessi, O.J.; Walker, D.M.; Ellis, P.; Dwyer, D.E. Fatal Staphylococcus aureus infective endocarditis. Oral. Surg. Oral Med. Oral Pathol. Oral Radiol. Endod., v.85, n.2, p.168-72, Feb. 1998. 